\title{
Dietzia, a New Genus Including Dietzia maris comb. nov., Formerly Rhodococcus maris
}

\author{
F. A. RAINEY, S. KLATTE, R. M. KROPPENSTEDT, AND E. STACKEBRANDT* \\ DSM-Deutsche Sammlung von Mikroorganismen und Zellkulturen GmbH, \\ D-38124 Braunschweig, Germany
}

\begin{abstract}
Sequencing of the 16S ribosomal DNAs (rDNA) of two strains of Rhodococcus maris was performed to determine the relationship of this species to other mycolic acid-containing actinomycetes. For this purpose we also determined the 16S rDNA sequences for the type species of the genus Rhodococcus, Rhodococcus rhodochrous, and for Mycobacterium chlorophenolicum (formerly Rhodococcus chlorophenolicus), Rhodococcus erythropolis, Gordona bronchialis, and Gordona terrae, for which only partial sequence data have been available previously. The sequences of the two strains of $R$. maris were identical. The results of a distance matrix analysis indicated that $R$. maris is not a member of the genus Rhodococcus but is located between members of the genus Corynebacterium and members of the Rhodococcus-Nocardia-Mycobacterium-Gordona-Tsukamurella cluster. The

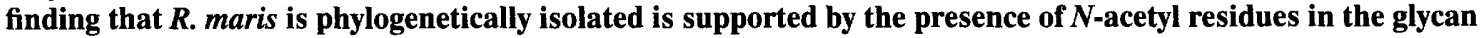
moiety of the peptidoglycan and the lack of phosphatidylinositol and phosphatidylinositol mannosides, characteristics which distinguish this taxon from related taxa. On the basis of our results and previous findings, we propose that $R$. maris should be reclassified in a new genus, Dietzia. The type species is Dietzia maris comb. nov.
\end{abstract}

Rhodococcus maris was originally known as "Flavobacterium maris" (9) but later was classified as a species of the genus Rhodococcus (17). The reason for this transfer was the presence of morphological and chemotaxonomic characteristics of the genus Rhodococcus, including gram-positive cells, lack of an aerial mycelium, cell wall chemotype IV, mycolic acids of the Rhodococcus erythropolis type, MK- $8\left(\mathrm{H}_{2}\right)$ as the major isoprenolog, fatty acids that included straight-chain saturated and monounsaturated fatty acids and tuberculostearic acid, and a DNA G+C content of $73.2 \mathrm{~mol} \%$. Differentiation from other Rhodococcus species was based on the results of physiological reactions. In this study we found that on the basis of additional chemotaxonomic data and phylogenetic evidence, $R$. maris cannot be considered an authentic member of the genus Rhodococcus.

\section{MATERIALS AND METHODS}

Bacterial strains and cultivation. $R$. maris DSM $43672^{\mathrm{T}}$ ( $\mathrm{T}=$ type strain) and DSM $46102, R$ erythropolis DSM $43066^{\mathrm{T}}$, Rhodococcus rhodochrous DSM $43241^{\mathrm{T}}$, Gordona bronchialis DSM $43247^{\mathrm{T}}$, Gordona terrae DSM $43249^{\mathrm{T}}$, and Mycobacterium chlorophenolicum (formerly Rhodococcus chlorophenolicus) DSM $43826^{\mathrm{T}}$ were grown on TSB agar ( $3 \%$ [wt/vol] Trypticase soy broth [BBL], $1.5 \%$ [wt/vol] Bacto Agar [Difco]) for 4 days at $28^{\circ} \mathrm{C}$.

16S rDNA sequencing. Genomic DNAs were extracted from two strains of $R$. maris, $R$. rhodochrous, $R$. erythropolis, $M$. chlorophenolicum, Corynebacterium glutamicum, $G$. bronchialis, and $G$. terrae and the $16 \mathrm{~S}$ ribosomal DNAs (rDNAs) were amplified as described previously (20). PCR products were sequenced directly by using a Taq DyeDeoxy Terminator Cycle sequencing kit (Applied Biosystems) according to the manufacturer's instructions. The sequence reaction products were electrophoresed by using an Applied Biosystems model 373A DNA sequencer. Bootstrap values, which were based on an analysis of 1,000 trees of 860 polymorphic sites, were calculated by using the programs NJFIND and NJBOOT.

Our sequences were manually aligned with previously published sequences for representatives of the main actinomycete sublines of descent included in the Ribosome Database Project (15) and for the organisms which we studied.

\footnotetext{
* Corresponding author. Mailing address: DSM-Deutsche Sammlung von Mikroorganismen und Zellkulturen GmbH, Mascheroder Weg 1B, D-38124 Braunschweig, Germany. Phone: 495312616352. Fax: 495312616 418. Electronic mail address: Stackebrandt@venus. gbf-braunschweig.d400.de.
}

Pairwise evolutionary distances were computed by using the correction of Jukes and Cantor (12). Phylogenetic analyses were carried out by using the algorithm of DeSoete (5).

Determination of the acyl type of murein. The acyl type of murein of $R$. maris was determined by a modification of the colorimetric method of Uchida and Aida (21). In contrast to the original procedure, our whole-cell hydrolysate was neutralized by passing it through an ion-exchange column (Analytichem Bond Elut SCX; Varian).

Lipid analysis. Free lipids were extracted from dry $R$. maris cell material (ca. $50 \mathrm{mg}$ ) as described by Minnikin et al. (16) and were analyzed by twodimensional thin-layer chromatography, using the method of Collins et al. (3). To analyze whole-cell fatty acids, fatty acid methyl esters were prepared from wet cells (40 to $70 \mathrm{mg}$ ) as described previously (14). A $0.3-\mathrm{ml}$ portion of the extract was passed through a silica gel column (Analytichem Bond Elut; Varian) to trap the mycolic acids, and the resulting preparation was then used for a gas chromatographic analysis of the fatty acid methyl esters. Trimethylsilylated derivatives of the free mycolic acids were prepared by mixing another aliquot of the extract with $0.1 \mathrm{ml}$ of a solution containing $n$-methyl- $n$-(trimethylsilyl)heptafluorobutyramide and trimethylchlorosilane (10:1, vol/vol; Macherey \& Nagel, Düren, Germany).

The mixtures of fatty acid methyl esters and trimethylsilylated derivatives of the free mycolic acids were analyzed by capillary gas chromatography, using a model 5898A Microbial Identification System apparatus (Microbial ID, Newark, Del.). For the fatty acid methyl ester analysis standard Microbial Identification System conditions were used. The trimethylsilylated derivatives of the mycolic acids were analyzed by high-temperature gas chromatography with a model HP 5790A gas chromatograph (Hewlett Packard) equipped with a flame ionization detector and a 12-m type HT5 column (part no. 051385; SGE, Victoria, Australia), using $\mathrm{H}_{2}$ as the carrier gas at a flow rate of $30 \mathrm{ml} / \mathrm{min}$. The oven temperature was increased from 210 to $400^{\circ} \mathrm{C}$ at a rate of $10^{\circ} \mathrm{C} / \mathrm{min}$, and the preparation was kept at the final temperature for $7 \mathrm{~min}$. Peaks of the derivatives were identified by comparing their retention times with the retention times of standards and by a gas chromatography-mass spectrometry analysis performed with a KRATOS MS50 spectrometer (ion source temperature, $200^{\circ} \mathrm{C}$; ionization energy, $70 \mathrm{eV}$ ).

Nucleotide sequence accession numbers. The $16 \mathrm{~S}$ rDNA nucleotide sequences which we determined have been deposited in the EMBL database under accession numbers X79286 through X79292.

\section{RESULTS AND DISCUSSION}

The almost complete 16S rDNA sequences of $R$. maris DSM $43672^{\mathrm{T}}$ and DSM 46102, consisting of 1,475 and 1,473 nucleotides, respectively, were compared with the sequences of three other Rhodococcus species, three Corynebacterium species, two Nocardia species, two Gordona species and Tsukamurella paurometabolum, as well as 10 additional species of 


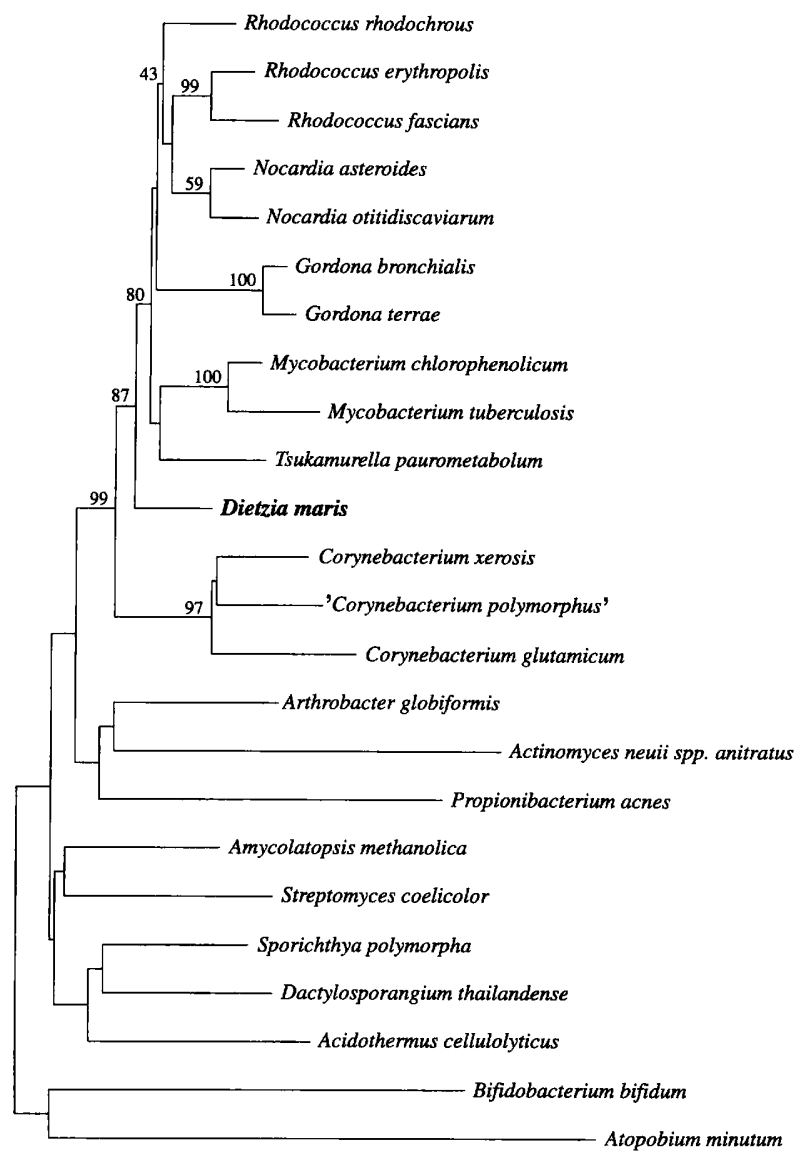

0.10

FIG. 1. Phylogenetic tree based on 16S rRNA gene sequences for $R$. maris (described in this paper as $D$. maris), members of other mycolic acid-containing genera, and other actinomycetes. The numbers are the estimated confidence levels, expressed as percentages, for the positions of the branches, as determined by a bootstrap analysis. Bar $=10 \%$ difference between sequences, as determined by measuring the lengths of the horizontal lines connecting two species.

actinomycetes that do not belong to the phylogenetically defined group of mycolic acid-containing taxa. In this study the members of each genus for which more than one species was analyzed formed an individual coherent cluster (Fig. 1). The transfer of $R$. chlorophenolicus to the genus Mycobacterium that was based on morphological and chemotaxonomic grounds (8) was supported by the results of the phylogenetic analysis (1). The species of each cluster exhibited 16S rDNA homology values of more than $94.9 \%$ (Table 1). Two species which, despite their generic assignments, did not group with other members of their genus were $R$. rhodochrous and $R$. maris. $R$. rhodochrous, the type species of the genus Rhodococcus, branched off slightly deeper than the other members of the genus Rhodococcus and the two Nocardia species. The corresponding 16S rDNA homology values ranged from 95.8 to $97.0 \%$. However, the bootstrap value of 43 obtained for the five species examined was statistically insignificant, and the branching point of $R$. rhodochrous may change when more organisms belonging to these or other genera are included in phylogenetic analyses. The phylogenetic position of $R$. maris, on the other hand, can be regarded as statistically more significant (level of confidence, 80\%). The two strains of this species examined, which had identical 16S rDNA sequences, branched off after the Corynebacterium line of descent, but before the main radiation that includes members of the genera Tsukamurella, Mycobacterium, Gordona, and Nocardia and the authentic Rhodococcus species. The 16S rDNA homology values for $R$. maris ranged from 93.2 to $95.9 \%$. The phylogenetic position of $R$. maris remained stable when the analysis was extended to include 15 Rhodococcus species, 10 Nocardia species, and four Gordona species (19). The uniqueness of the $16 \mathrm{~S}$ rDNA of $R$. maris was expressed by the presence of a few signature nucleotides that were not shared by other organisms included in the analysis. These nucleotides were found at positions (Escherichia coli nomenclature [2]) 418 to 425 (U-A), 614 to 626 (U-G), 837 to 849 (G-C), and 987 to 1218 (A-U).

The distinct position of $R$. maris outside the radiation of the mycolic acid-containing bacteria indicates that this species merits genus status. In order to compare chemotaxonomic properties that are known to be of taxonomic value for members of this group, we determined the acyl type of murein, the fatty acid composition, the polar lipids, and the numbers of carbons in the parent mycolic acids for $R$. maris (Table 2). The fatty acid spectrum of $R$. maris is similar to the spectra found for all of the other mycolic acid-containing taxa except the genus Corynebacterium; the fatty acids include mainly straightchain saturated types (6\% 15:0, 33\% 16:0, 6\% 17:0 [percentages of the total fatty acids]) and monounsaturated types (13\% $16: 1,15 \% 17: 1,18 \% 18: 1)(6,7)$. The polar lipids are phosphatidylethanolamine, phosphatidylglycerol, and diphosphatidylglycerol. Phosphatidylinositol and phosphatidylinositol mannosides are not present (Fig. 2), which distinguishes $R$. maris from all other related taxa. The presence of phosphatidylethanolamine distinguishes $R$. maris from Corynebacterium species. The ability to synthesize tuberculostearic acid (12\% of the total fatty acids) is shared with members of the genera Nocardia, Rhodococcus, Gordona, and Tsukamurella. The presence of this fatty acid has been reported in only a few Corynebacterium species $(10,18)$. The numbers of carbon atoms in the mycolic acids fell in a relatively narrow range (34 to 38 carbon atoms; $14 \% \mathrm{C}_{34}, 21 \% \mathrm{C}_{35}, 35 \% \mathrm{C}_{36}, 16 \% \mathrm{C}_{37}, 9 \%$ $\mathrm{C}_{38}$ ); these mycolic acids are shorter than those reported for the other members of the genus Rhodococcus, whose mycolic acids have 34 to 52 carbon atoms $(4,6)$. R. maris, as well as Corynebacterium species, contains the common $N$-acetylmuramic acid residue, while all other members of the related taxa contain the rare compound $N$-glycolylmuramic acid (7). On the basis of phylogenetic (Fig. 1) and chemotaxonomic evidence (Table 2), the description of a new genus for $R$. maris appears to be justified. Below the generic name Dietzia is proposed to accommodate this species. With the description of Dietzia maris and the recent exclusion of $R$. chlorophenolicus (now $M$. chlorophenolicum [1, 8]) and Rhodococcus aichiensis (now Gordona aichiensis [13]), the genus Rhodococcus no longer contains several formerly misclassified species, which should eventually facilitate unambiguous definition of this genus of ecological, biotechnological, and medical importance.

Description of Dietzia gen. nov. Dietzia (Diet'zi.a. M.L. dim. ending -ia; M.L. fem. n. Dietzia, honoring Alma Dietz, an American microbiologist). Gram-positive, non-spore-forming cocci that germinate into short rods. Aerobic and chemoorganotrophic. Catalase positive. Rod-shaped cells exhibit a morphogenetic cycle. The diagnostic amino acid of the peptidoglycan is meso-diaminopimelic acid (variation $\mathrm{Al} \gamma$ ); the glycan moiety of cell walls contains $N$-acetyl residues $(N$ acetylmuramic acid). The major cell wall sugars are arabinose and galactose. Short-chain mycolic acids are present (overall size, 34 to 38 carbon atoms). The long-chain cellular fatty acids are predominantly straight-chain saturated and monounsat- 


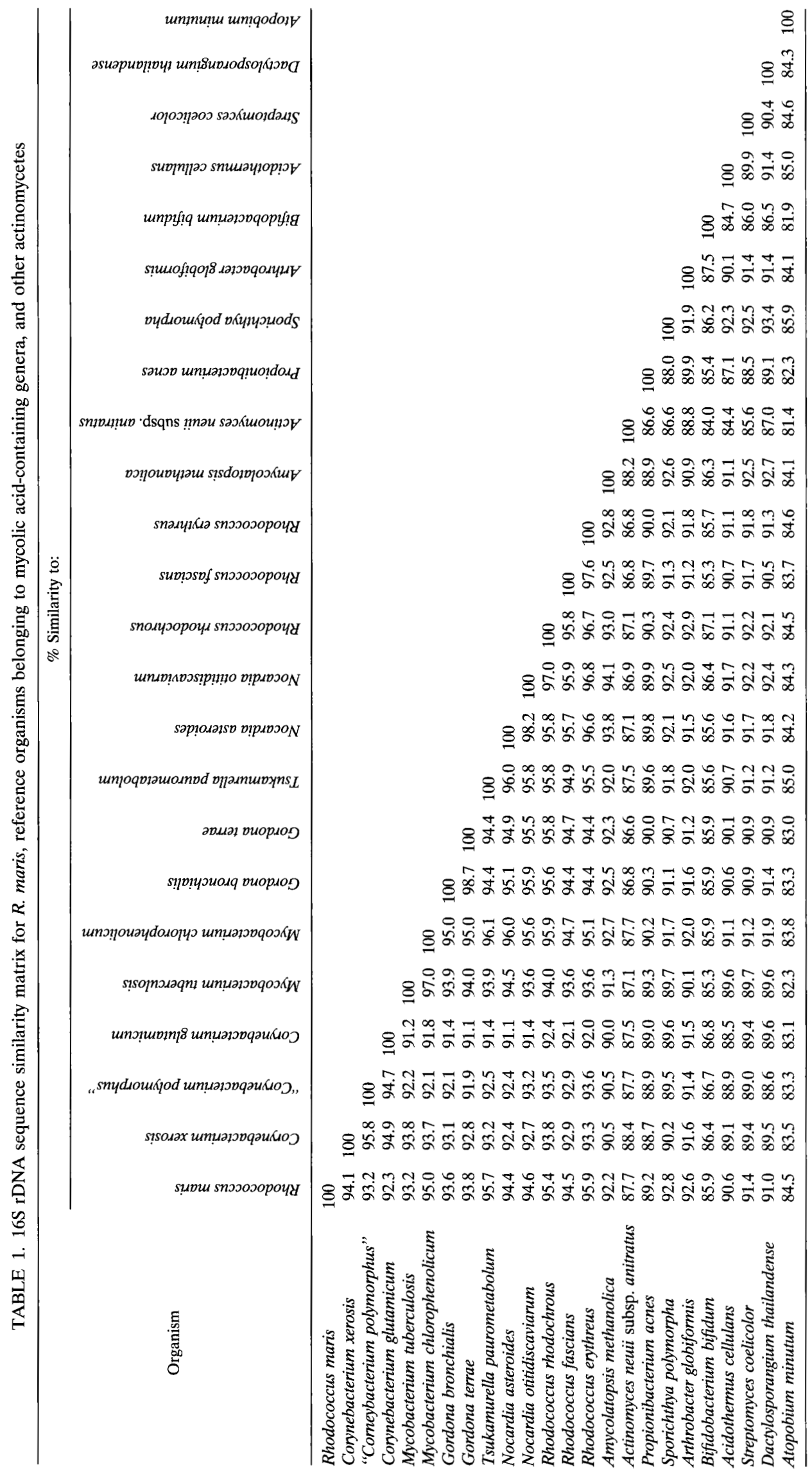


TABLE 2. Differential chemotaxonomic characteristics of the genus Dietzia and other mycolic acid-containing genera ${ }^{a}$

\begin{tabular}{|c|c|c|c|c|c|c|c|c|}
\hline \multirow[b]{2}{*}{ Genus } & \multirow[b]{2}{*}{$\begin{array}{l}\text { Overall no. of } \\
\text { carbon atoms in } \\
\text { mycolic acids }\end{array}$} & \multirow[b]{2}{*}{$\begin{array}{l}\text { Fatty acid } \\
\text { type }^{b}\end{array}$} & \multicolumn{3}{|c|}{ Presence of: } & \multirow[b]{2}{*}{ Menaquinone(s) } & \multirow{2}{*}{$\begin{array}{l}N \text {-Glycolyl } \\
\text { in glycan } \\
\text { moiety of } \\
\text { wall }\end{array}$} & \multirow{2}{*}{$\begin{array}{l}\text { Guanine-plus } \\
\text { cytosine } \\
\text { content of } \\
\text { DNA (mol\%) }\end{array}$} \\
\hline & & & $\begin{array}{l}\text { Tuberculo- } \\
\text { stearic acid }\end{array}$ & $\begin{array}{l}\text { Phosphatidyl- } \\
\text { ethanolamine }\end{array}$ & $\begin{array}{l}\text { Phosphatidyinositol and } \\
\text { phosphatidylinositol } \\
\text { mannosides }\end{array}$ & & & \\
\hline Dietzia & $34-38$ & 1B & + & + & - & $\mathrm{MK}-8\left(\mathrm{H}_{2}\right)$ & - & 73 \\
\hline Corynebacterium & $22-36$ & $1 \mathrm{~A}^{c}$ & - & $-^{d}$ & + & MK- $8\left(\mathrm{H}_{2}\right)$, MK- $9\left(\mathrm{H}_{2}\right)$ & - & $51-67$ \\
\hline Gordona & $48-66$ & $1 \mathrm{~B}$ & + & + & + & MK-9( $\left.\mathrm{H}_{2}\right)$ & + & $63-69$ \\
\hline Mycobacterium & $60-90$ & $1 \mathrm{~B}$ & + & + & + & MK-9(H) & + & $72-70$ \\
\hline Nocardia & $44-60$ & $1 \mathrm{~B}$ & + & + & + & MK- $8\left(\mathrm{H}_{4}, \omega-\mathrm{cycl}\right)^{e}$ & + & $64-72$ \\
\hline Rhodococcus & $34-64$ & $1 \mathrm{~B}$ & + & + & + & MK- $8\left(\mathrm{H}_{2}\right)$ & + & $63-73$ \\
\hline Tsukamurella & $64-78$ & $1 \mathrm{~B}$ & + & + & + & MK-9 & + & $67-68$ \\
\hline
\end{tabular}

${ }^{a}$ Data from references 4,7 , and 19 .

${ }^{b}$ Fatty acids types as defined in reference 14 .

${ }^{c}$ Some Connebacterium species have fatty acid type $1 \mathrm{~B}(10,18)$.

${ }^{d}$ Some Corynebacterium species contain phosphatidylethanolamine $(10,18)$

${ }^{e}$ Data from reference 11.

urated fatty acids. Tuberculostearic acid is present. The major polar lipids are phosphatidylethanolamine, phosphatidylglycerol, and diphosphatidylglycerol. Phosphatidylinositol and phosphatidylinnositol mannosides are absent. Menaquinone MK-8 $\left(\mathrm{H}_{2}\right)$ is the major isoprenolog. The guanine-plus-cytosine content of the DNA is $73 \mathrm{~mol} \%$ (as determined by the thermal denaturation method).

Phylogenetically, the genus is a member of the mycolic acid-containing group consisting of the genera Corynebacterium, Mycobacterium, Nocardia, Rhodococcus, Tsukamurella, and Gordona. The type species is D. maris. The genus Dietzia can be readily distinguished from other mycolic acid-containing taxa by the criteria shown in Table 2 .

Description of Dietzia maris (Nesterenko, Nogina, Kasumova, Kvasnikov, and Batrakov 1982) comb. nov. Dietzia maris (mar'is. L. gen. n. maris, of the sea). The description below is based on data from references 6,9 , and 17 . Coccoid cells germinate into short rods which exhibit snapping division

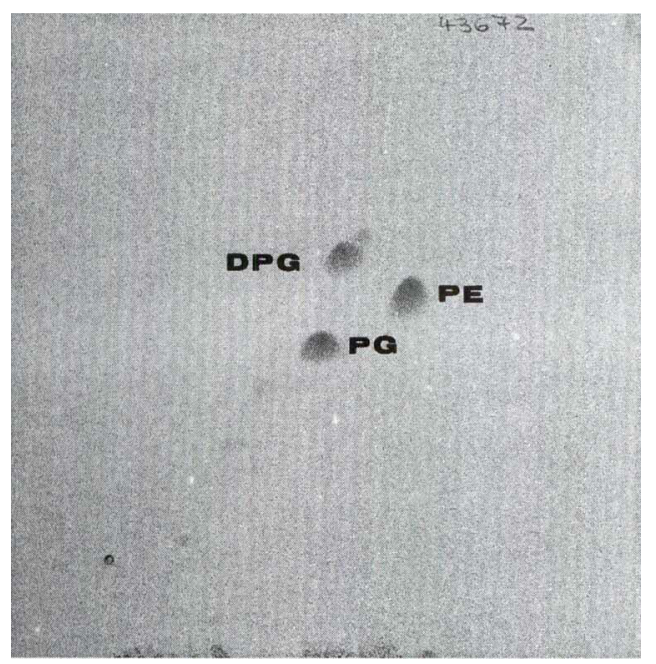

FIG. 2. Two-dimensional thin-layer chromatogram of phospholipids of $R$. maris DSM $43672^{\mathrm{T}}$. The chromatographic conditions were as follows. Silica Gel 60 thin-layer plates $(10$ by $10 \mathrm{~cm}$ ) were spotted with $20 \mu \mathrm{l}$ of a whole-cell lipid extract by using the procedure of Minnikin et al. (16). Chloroform-methanolwater $(65: 24: 4, \mathrm{vol} / \mathrm{vol} / \mathrm{vol})$ was used in the first direction, and chloroform-acetic acid-methanol-water $(80: 15: 12: 4, \mathrm{vol} / \mathrm{vol} / \mathrm{vol} / \mathrm{vol})$ was used in the second direction. The plate was sprayed with ninhydrin and then with molybdenum blue reagent to locate and differentiate the phospholipids. Abbreviations: PG, phosphatidylglycerol; DPG, diphosphatidylglycerol; PE, phosphatidylethanolamine. and produce $\mathrm{V}$ forms. Poor to moderate, butyrous, orange growth occurs on glycerol, nutrient, and wort agar media. Circular, raised, butyrous, glistening colonies with entire margins are formed on nutrient agar. Growth in nutrient broth is turbid.

Acetylmethylcarbinol, indole, methyl red, $p$-nitrophenoloxidase, and phosphatase tests are negative. Hydrogen sulfide is not produced.

Acid is produced from fructose, glycerol, and glucose but not from ribitol, arabinose, cellobiose, galactitol, galactose, inositol, lactose, maltose, mannitol, $\alpha$-methyl-D-glucose, raffinose, rhamnose, salicin, glucitol, sorbose, sucrose, or xylose.

Growth occurs with $\mathrm{C}_{6}$ to $\mathrm{C}_{17}, \mathrm{C}_{19}$, and $\mathrm{C}_{23} n$-alkanes but not with ethane or methane.

Isolated from soil and from skin and intestinal tracts of carp (Cyprinus carpio).

The guanine-plus-cytosine content of the DNA is $73 \mathrm{~mol} \%$ (as determined by the thermal denaturation method).

The type strain is IMV 195 (= DSM 43672 = ATCC 35013 $=$ JCM 6166).

\section{ACKNOWLEDGMENT}

We thank Gabriele Pötter for the polar lipid analyses.

\section{REFERENCES}

1. Briglia, M., R. I. L. Eggen, D. J. Van Elsas, and W. M. De Vos. 1994. Phylogenetic evidence for transfer of pentachlorophenol-mineralizing Rhodococcus chlorophenolicus PCP- $\mathrm{I}^{\mathrm{T}}$ to the genus Mycobacterium. Int. J. Syst. Bacteriol. 44:494-498.

2. Brosius, J., J. J. Palmer, J. P. Kennedy, and H. F. Noller. 1978. Complete nucleotide sequence of a $16 \mathrm{~S}$ ribosomal RNA gene from Escherichia coli. Proc. Natl. Acad. Sci. USA 75:4801-4805.

3. Collins, D., T. Pirouz, M. Goodfellow, and D. E. Minnikin. 1977. Distribution of menaquinones in actinomycetes and corynebacteria. J. Gen. Microbiol. 100:221-230.

4. Collins, M. D., M. Goodfellow, and D. E. Minnikin. 1982. A survey of the structures of mycolic acids in Corynebacterium and related taxa. J. Gen. Microbiol. 128:129-149.

5. De Soete, G. 1983. At least squares algorithm for fitting additive trees to proximity data. Psychometrika 48:621-626.

6. Goodfellow, M. 1986. Genus Rhodococcus, p. 1472-1481. In P. H. A. Sneath, N. S. Mair, M. E. Sharpe, and J. G. Holt (ed.), Bergey's manual of systematic bacteriology, vol. 2. Williams \& Wilkins Co., Baltimore.

7. Goodfellow, M. 1992. The family Nocardiaceae, p. 1188-1212. In A. Balows, H. G. Trüper, M. Dworkin, W. Harder, and K. H. Schleifer (ed.), The procaryotes, 2nd ed. Springer-Verlag, New York.

8. Häggblom, M. M., L. J. Liesa, N. Nohynek, N. J. Palleroni, K. Kronqvist, E.-L. Nurmiaho-Lassila, M. S. Salkinoja-Salonen, S. Klatte, and R. M. Kroppenstedt. 1994. Transfer of polychlorophenol-degrading Rhodococcus chlorophenolicus (Apajalahti et al. 1986) to the genus Mycobacterium as 
Mycobacterium chlorophenolicum comb. nov. Int. J. Syst. Bacteriol, 44:485493.

9. Harrison, F. C. 1929. The discoloration of halibut. Can. J. Res. 1:214-239

10. Herrera-Alcaraz, E. A., P. L. Valero-Guillén, F. Martin-Luengo, and F. Soriano. 1990. Taxonomic implications of the chemical analysis of the D2 group of corynebacteria. FEMS Microbiol. Lett. 73:341-344.

11. Howard, O. W., E. Grund, R. M. Kroppenstedt, and M. D. Collins. 1986. Structural determination of a new naturally occurring cyclic vitamin $\mathrm{K}$. Biochem. Biophys. Res. Commun. 140:916-923.

12. Jukes, T. H., and C. R. Cantor. 1969. Evolution of protein molecules, p. 21-132. In H. N. Munro (ed.), Mammalian protein metabolism. Academic Press, Inc., New York.

13. Klatte, S., F. A. Rainey, and R. M. Kroppenstedt. 1994. Transfer of Rhodococcus aichiensis Tsukamura 1982 and Nocardia amarae Lechevalier and Lechevalier 1974 to the genus Gordona as Gordona aichiensis comb. nov. and Gordona amarae comb. nov. Int. J. Syst. Bacteriol. 44:769-773.

14. Kroppenstedt, R. M. 1985. Fatty acid and menaquinone analysis of actinomycetes and related organisms. Soc. Appl. Bacteriol. Techn. Ser. 20:173-199.

15. Larsen, N., G. J. Olsen, B. L. Maidak, M. J. McCaughey, R. Overbeek, T. J. Macke, T. L. Marsh, and C. R. Woese. 1993. The ribosomal database project. Nucleic Acids Res. 21:3021-3023.
16. Minnikin, D. E., A. G. O'Donnell, M. Goodfellow, G. Alderson, M. Athalye, A. Schaal, and J. H. Parlett. 1984. An integrated procedure for extraction of bacterial isoprenoid quinones and polar lipids. J. Microbiol. Methods 2: 233-241.

17. Nesterenko, O. A., T. M. Nogina, S. A. Kasumova, E. I. Kvasnikow, and S. G. Batrakov. 1982. Rhodococcus luteus nom. nov, and Rhodococcus maris nom. nov. Int. J. Syst. Bacteriol. 32:1-14.

18. Pitcher, D., A. Soto, F. Soriano, and P. Valero-Guillén. 1992. Classification of coryneform bacteria associated with human urinary tract infection (group D2) as Corynebacterium urealyticum sp. nov. Int. J. Syst. Bacteriol. 42:178181 .

19. Rainey, F. A., J. Burghardt, R. M. Kroppenstedt, S. Klatte, and E. Stackebrandt. Phylogenetic analysis of the genera Rhodococcus and Nocardia and evidence for the evolutionary origin of the genus Nocardia from within the radiation of Rhodococcus specles. Microbiology, in press.

20. Rainey, F. A., M. Dorsch, H. W. Morgan, and E. Stackebrandt. 1992. 16S rDNA analysis of Spirochaeta thermophila: its phylogenetic position and implications for the systematics of the order Spirochaetales. Syst. Appl. Microbiol. 15:197-202.

21. Uchida, K., and K. Aida. 1977. Acyl type of bacterial cell wall: its simple identification by a colorimetric method. J. Gen. Microbiol. 23:249-260. 